\title{
中枢神経系原発悪性リンパ腫の臨床的検討
}

$$
\begin{array}{llllllll}
\text { 吉 } \text { 田真 三 } & \text { 松 } & \text { 本 茂 男 } \text { 佐 } & \text { 藤 慎 一 } \\
\text { 本 崎 孝 彦 } & \text { 伴 } & \text { 貞 彦 } \text { 山 } & \text { 本 豊 城 }
\end{array}
$$

\section{Management Results in Primary Central Nervous System Lymphoma \\ by}

\author{
Shinzo Yoshida, M.D., Shigeo Matsumoto, M.D., Shinichi Sato, M.D., Takahiko Motozaki, M.D., \\ Sadahiko Ban, M.D., and Toyoshiro Yamamoto, M.D.
}

$$
\text { from }
$$

Department of Neurosurgery, Kobe City General Hospital

Fourteen cases of primary central nervous system lymphoma (PCNSL) are reported with emphasis upon correlation between the clinical course and CT findings. All primary lesions were intracranially located, presenting either single or multiple intracerebral nodules with contrast enhancement on CT scan. Mental disturbance was the most common neurological manifestation on admission. All patients were given radiation therapy as the initial treatment except one, who showed complete remission in response to corticosteroid administration. Steroid induced tumor regression on CT in 4 out of 8 patients, including 3 cases of complete remission. The initial treatment induced complete disappearance of the tumor nodules showing contrast enhancement in all but 1 patient, who died in the course of the treatment. However, clinical improvement did not always follow the disappearance of the tumor on $\mathrm{CT}$ scan. The patients with mental disturbance and multiple tumors tended to show an inadequate response to treatment.

During the follow-up period, 9 patients died. The cause of death was attributable to the uncontrolled growth of recurrent tumors, with contrast enhancement on $\mathrm{CT}$, in only 2 patients. In the remaining 7 , a diffuse low density area appeared in the deep cerebral white matter, with ventricular dilatation of varying degree in the follow-up period. When CT scan disclosed these findings, the patients showed a disability similar to that of normal pressure hydrocephalus, usually in a bed-ridden state, thereafter gradually deteriorating until death.

In this study, the tumor nodules showing contrast enhancement seemed to be treated with relative ease. The diffuse low density, on the contrary, was much more difficult to deal with and was considered to be a major obstacle to improving the treatment results in PCNSL.

(Received September 28, 1992 ; accepted March 3, 1993)

Key words : primary central nervous system lymphoma, irradiation, corticosteroid, management result

Jpn J Neurosurg (Tokyo) $2: 288-294,1993$

\section{はじめに}

中枢神経系に限局した non-Hodgkin's lymphoma で ある中枢神経系原発悪性リンパ腫 (primary central nervous system lymphoma, 以下 PCNSL) は, 従来稀な
疾患とされてきたが, 近年著しい症例数の増加が指摘さ れており6)，今日では頭蓋内腫瘍の鑑別診断において重 要な位置を占めつつある．著明な放射線感受性を示すこ とより, その治療はこれまで放射線治療を中心として展 開されてきた 319)18) 19120123)。初回放射線治療により多く の症例において緩解を得ることが可能であるにもかかわ

神戸中央市民病院脳神経外科（連絡先：吉田真三， $\mathrm{T} 650$ 神戸市中央区港島中町 4-6)

Address reprint requests to : Shinzo Yoshida, M. D., Minatojima-Nakamachi 4-6, Chuo-ku, Kobe-shi, 650 Hyogo, Japan 
Table 1 Summary of cases

\begin{tabular}{|c|c|c|c|c|c|c|c|}
\hline Case & Age & Sex & Location & $\begin{array}{c}\text { Response to } \\
\text { steroid }\end{array}$ & Initial treatment & Recurrence & Outcome \\
\hline 1 & 68 & M & $\begin{array}{l}\text { Multiple } \\
\text { BG, O, C }\end{array}$ & $(-)$ & $\begin{array}{l}\text { WB } 38 \text { Gy } \\
\text { ACNU }\end{array}$ & $/$ & $\begin{array}{c}\text { Dead } \\
3 \text { months }\end{array}$ \\
\hline 2 & 21 & $\mathrm{~F}$ & $\begin{array}{l}\text { Single } \\
\text { Temporal }\end{array}$ & $(-)$ & WB 30Gy, Local 16Gy & $\begin{array}{c}(+) \\
48 \text { days }\end{array}$ & $\begin{array}{c}\text { Dead } \\
3 \text { months }\end{array}$ \\
\hline 3 & 66 & M & $\begin{array}{l}\text { Single } \\
\text { Temporal }\end{array}$ & $(+)$ & WB 46Gy & $(-)$ & $\begin{array}{c}\text { Dead } \\
7 \text { months }\end{array}$ \\
\hline 4 & 75 & M & $\begin{array}{l}\text { Multiple } \\
\text { C, CC }\end{array}$ & $(-)$ & WB 48Gy & $\begin{array}{c}(+) \\
4 \text { months }\end{array}$ & $\begin{array}{c}\text { Dead } \\
8 \text { months }\end{array}$ \\
\hline 5 & 37 & M & $\begin{array}{l}\text { Single } \\
\text { Frontal }\end{array}$ & / & $\begin{array}{l}\text { WB } 41 G y \\
\text { VEMP }\end{array}$ & $\begin{array}{c}(+) \\
12 \text { months }\end{array}$ & $\begin{array}{c}\text { Dead } \\
18 \text { months }\end{array}$ \\
\hline 6 & 74 & M & $\begin{array}{l}\text { Multiple } \\
\text { BG }\end{array}$ & $(-)$ & WB 40Gy, Local 16Gy & $\begin{array}{c}(+) \\
11 \text { months }\end{array}$ & $\begin{array}{c}\text { Dead } \\
20 \text { months }\end{array}$ \\
\hline 7 & 70 & $\mathrm{~F}$ & $\begin{array}{l}\text { Single } \\
\text { Suprasellar }\end{array}$ & $(+) \mathrm{CR}$ & $\begin{array}{l}\text { Local } 40 \mathrm{~Gy} \\
\text { ACNU }\end{array}$ & $\begin{array}{c}(+) \\
64 \text { days }\end{array}$ & $\begin{array}{c}\text { Dead } \\
33 \text { months }\end{array}$ \\
\hline 8 & 34 & M & $\begin{array}{l}\text { Multiple } \\
\text { BG, BS }\end{array}$ & ? & Local 46Gy & $\begin{array}{c}(+) \\
5 \text { months }\end{array}$ & $\begin{array}{c}\text { Dead } \\
33 \text { months }\end{array}$ \\
\hline 9 & 70 & $\mathrm{~F}$ & $\begin{array}{l}\text { Multiple } \\
\text { Frontal, CC }\end{array}$ & $(+) \mathrm{CR}$ & WB 30Gy, Local 16Gy & $(-)$ & $\begin{array}{c}\text { Dead } \\
35 \text { months }\end{array}$ \\
\hline 10 & 53 & M & $\begin{array}{l}\text { Multiple } \\
\text { Periventricular }\end{array}$ & $(+) \mathrm{CR}$ & / & $\begin{array}{c}(+) \\
60 \text { months }\end{array}$ & $\begin{array}{c}\text { Dead } \\
84 \text { months }\end{array}$ \\
\hline 11 & 67 & $\mathrm{~F}$ & $\begin{array}{l}\text { Multiple } \\
\text { Frontal, BG }\end{array}$ & ? & WB 46Gy, Local 9Gy & $\begin{array}{c}(+) \\
2 \text { months }\end{array}$ & Unknown \\
\hline 12 & 63 & $\mathrm{M}$ & $\begin{array}{l}\text { Single } \\
\mathrm{C}\end{array}$ & I & Local 42Gy & $\begin{array}{c}(+) \\
3 \text { months }\end{array}$ & $\begin{array}{c}\text { Alive } \\
18 \text { months }\end{array}$ \\
\hline 13 & 38 & $\mathrm{~F}$ & $\begin{array}{l}\text { Single } \\
\text { Intraventricular }\end{array}$ & $(-)$ & $\begin{array}{l}\text { WB } 42 \text { Gy, Local 18Gy } \\
\text { VEPA }\end{array}$ & $(-)$ & $\begin{array}{c}\text { Alive } \\
24 \text { months }\end{array}$ \\
\hline 14 & 52 & $\mathrm{M}$ & $\begin{array}{l}\text { Multiple } \\
\text { Periventricular }\end{array}$ & $?$ & WB 32Gy, Local 12Gy & $\begin{array}{c}(+) \\
60 \text { months }\end{array}$ & $\begin{array}{c}\text { Alive } \\
62 \text { months }\end{array}$ \\
\hline
\end{tabular}

BG : basal ganglia $\mathrm{O}$ : occipital $\mathrm{C}$ : cerebellum $\mathrm{CC}$ : corpus callosum $\mathrm{BS}:$ brain stem CR : complete response WB : whole brain irradiation VEMP : vincristin, endoxan (cyclophosphamide), 6-mercapto-purine, prednisolone VEPA : vincristin, endoxan (cyclophosphamide), prednisolone, adriamycin ?: unable to evaluate

らず，通常短期間で再発をきたし長期生存例は稀とされ ている、しかしながら，予後不良症例において必ずしも CT 上明らかな占拠性病変の再発が出現するわけではな く, CT 上明らかな再発病変なく, 疾呆症状から徐々に 全身状態が悪化し死亡に至る症例が臨床上しばしば経験 される．今回われわれは放射線治療を中心とした初回治 療を行った 14 例の PCNSL について, 治療成績, CT 所 見を中心とした初回治療後の臨床経過の検討を行い, 興 味ある知見を得たので報告する。

\section{対象亡方法}

検討対象は 1981〜1990 年までの間に，当科において PCNSL として診断され, 放射線照射を中心とした初回 治療を行った 14 例 (Table 1) である. 年齢は 21〜 75 歳, 平均 56 歳, 性別は男性 9 例, 女性 5 例であった. AIDS, 臟器移植後, その他の免疫不全を合併した症例はみられ なかった。また全身性リンパ腫の除外診断は, 胸部X線,
腹部超音波診断, ガリウムシンチ, 骨シンチを routine に 行い，また必要に応じて骨髄穿刺を施行した。診断は， 組織診断により確定したもの5例, 䯣液細胞診により診 断したもの 1 例で，その他の 8 例は CT 所見, corticosteroid 投与に対寸る反応性などから臨床的に PCNSL と診断した.初回治療において 12 例で corticosteroidの 投与を行った.うち 1 例 (Case 10) は, corticosteroid 投 与のみで初回治療を終了した.その他の 13 例における初 回治療の内容は, corticosteroid を除けば放射線治療単 独 9 例, 放射線治療後 adjuvant therapy として化学療 法を追加したもの 4 例であった. 放射線治療の内容は局 所照射のみ 3 例, 全脳照射のみ 4 例, 全脳照射後局所照 射を追加したもの 6 例であった. 初回治療中に死亡した 1 例 (Case 1) を除いて, 全例局所には少なくとも $40 \mathrm{~Gy}$ 以上の照射を行った。 


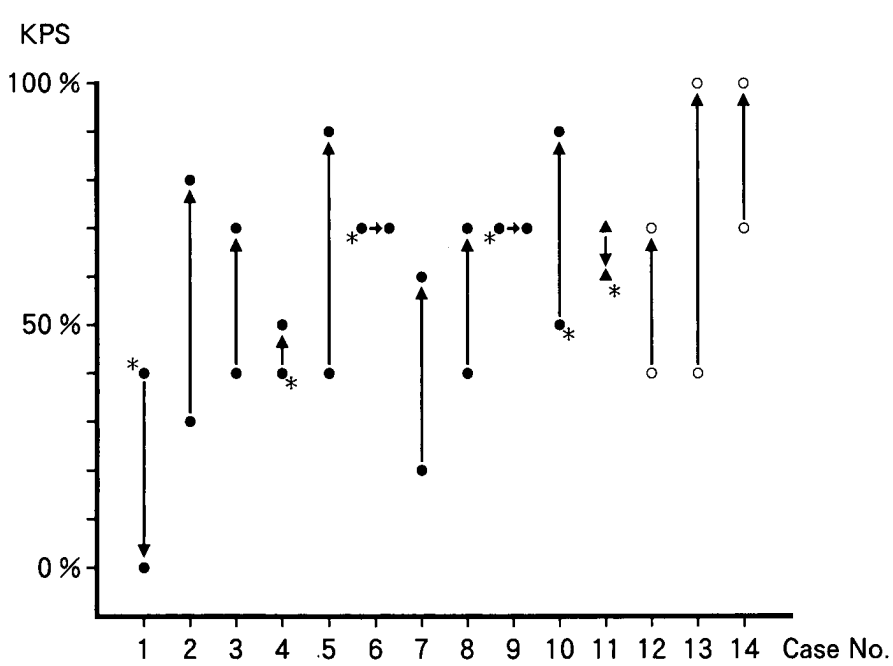

Fig. 1 Karnofsky performance status (KPS) before and after initial treatment

Clinical improvement is poor in patients with dementia and multiple tumors (indicated by ${ }^{*}$ ). Black circles and open circles show dead and alive patients, respectively. The case with a triangle was not followed.

\section{結 果}

入院時の神経症状としては, 記銘力障害, 見当識障害, 行動異常などの痴呆様症状が 14 例中 7 例に認められ, 最 も頻度が高かった。全例頭蓋内病変を初発とし, 春髄原 発のものはなかった。頭部 CT 上全例 contrast enhancement (以下, CE) を受ける nodular lesion を示し, 単 発病変 6 例, 多発病変 8 例であった. 神経症状と CT 所 見については，前述の痴呆症状を示した 7 例のうち， 6 例が基底核，側脳室周囲深部白質等を含む多発性病変で あり, 残り 1 例は水頭症に起因する症状であった。病理 組織像は全例 LSG 分類 ${ }^{21)}$ による NHL diffuse type で あり, large cell type 4 例, medium cell type 1 例で あった．初回治療において corticosteroid の投与を行っ た 12 症例のうち, CT 上投与効果の判定が可能であった 9 例中 4 例に打いて CT 上腫瘍の縮小を認め, うち 3 例 は complete response (以下, CR) を示した. 初回治療 中 1 例が重篤な骨髄抑制から敗血症となり死亡した (Case 1).この症例を除く 13 例全例において頭部 CT 上 $\mathrm{CE}$ を示す病変は $\mathrm{CR}$ となった。初回治療において $\mathrm{CR}$ の得られた 13 例について治療前後の Karnofski performance status を Fig. 1 に示した. 画像所見の改善と臨 床症状の改善は必ずしも一致せず，13 例全体で performance status (以下，PS) が 80\%以上となったものは 5 例のみであった．PS の改善が不良にとどまった症例で は，その多くは痴呆症状の改善が不良であったことに起
因しており，運動麻痺，構音障害などの巣症状の改善が 比較的良好であったのに比べて対照的であった．治療前 多発性病変でかつ痴呆症状を示した症例 (Case 4，6，9, 10，11）では特に PS の改善は不良であり，5例中完全 自立と考えられる PS $80 \%$ 以上に改善したのは 1 例のみ (Case 10) であり，また残りの 4 例のうち 3 例 (Case 6, 9，11) では PS は不変または悪化を示した。

初回治療により CR となった 13 例のうち, その後再発 をきたした症例は 10 例あり,初回再発までの期間は 1 力 月〜 5 年, 平均 11.9 力月であった. 初回再発部位は中枢 神経系内 8 例，中枢神経系外 2 例であった。中枢神経系 内に抢ける初回再発はすべて脳内病変であり，CT 上の $\mathrm{CE}(+)$ 病変において明らかに原発病変と連続性を有す る再発例が 1 例, $\mathrm{CE}(+)$ の原発病変とは直接連続性が ないが近接した部位における再発が 2 例，小脳半球と脳 梁などのように全く離れた遠隔部位に $\mathrm{CE}(+)$ 病変の 再発を認めたものが 5 例であった。初回再発において髄 腔内播種によると考えられた病変は認められなかった。 4 例において 2 回以上の再発を認めた。髄腔内播種によ ると考えられる脊髄への転移を認めた症例以外は，2 回 目以後の再発病変は過去の病変部位またはその近傍で あった。

初回治療において CR となった 13 例中 12 例が follow up されており，このうち 9 例がすでに死亡してい る. 全死亡例 10 例での平均生存期間は 24 力月, 最長生 存期間は 86 力月であった。また現在生存例での最長生存 例は 62 力月である.初回放射線治療における全脳照射の 有無抢よび総線量と予後の間には明らかな関連は見出せ なかった。また CT 上 $\mathrm{CE}(+)$ を示す中枢神経系内再 発病変は 9 例において計 13 回みられ,これに対し 2 回は ステロイドのみ, 11 回は放射線照射の追加，化学療法を 単独または併用で行った，ステロイドのみの投与 2 回で はいずれも NC (no change), 放射線照射の追加単独で は CR 2 回，評価不明 1 回，放射線および化学療法の併 用 (ACNU) では CR 1 回, PR (partial response) 1 回，化学療法単独 (VEMP 1, ACNU 2, CDDP+ VP-16 3) では CR 5 回, NC 1 回であった。

初回治療において CR となり, その後死亡した 9 症例 の死亡に至るまでの経過は，A群：CE を呈する再発腫 瘍の制御不能による死亡 2 例 (Case 2, 5), B 群: CT 上 $\mathrm{CE}$ を示す頭蓋内病変の再発がみられないか, みられて も mass effect に乏しく，これに対し大脳深部白質に広 範な低吸収域の出現を認めたもの 7 例 (Case 3, 4, 6, 7, $8 ， 9 ， 10)$ ，の 2 群に分類された。B群はいずれも疾呆症 状が徐々に進行し, 寝たきりの状態から次第に全身衰弱 

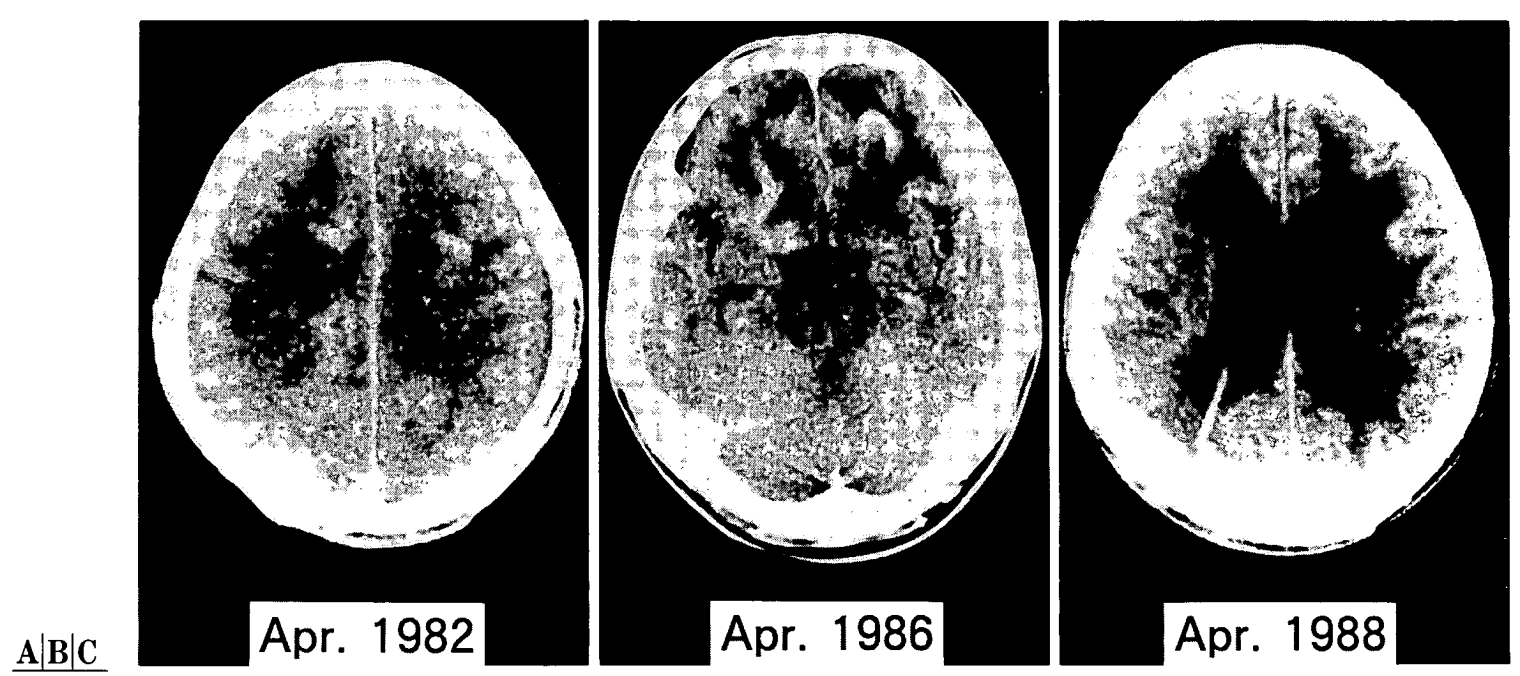

Fig. 2 Serial CT scans of Case 10

A : CT scan on initial admission shows multiple contrast-enhanced nodules in the deep cerebral white matter.

B : The recurrent tumor is evident in the frontal lobes.

C : Ventricular dilatation and diffuse low density area in the deep cerebral white matter are shown, although tumor recurrence with contrast enhancement is not found.
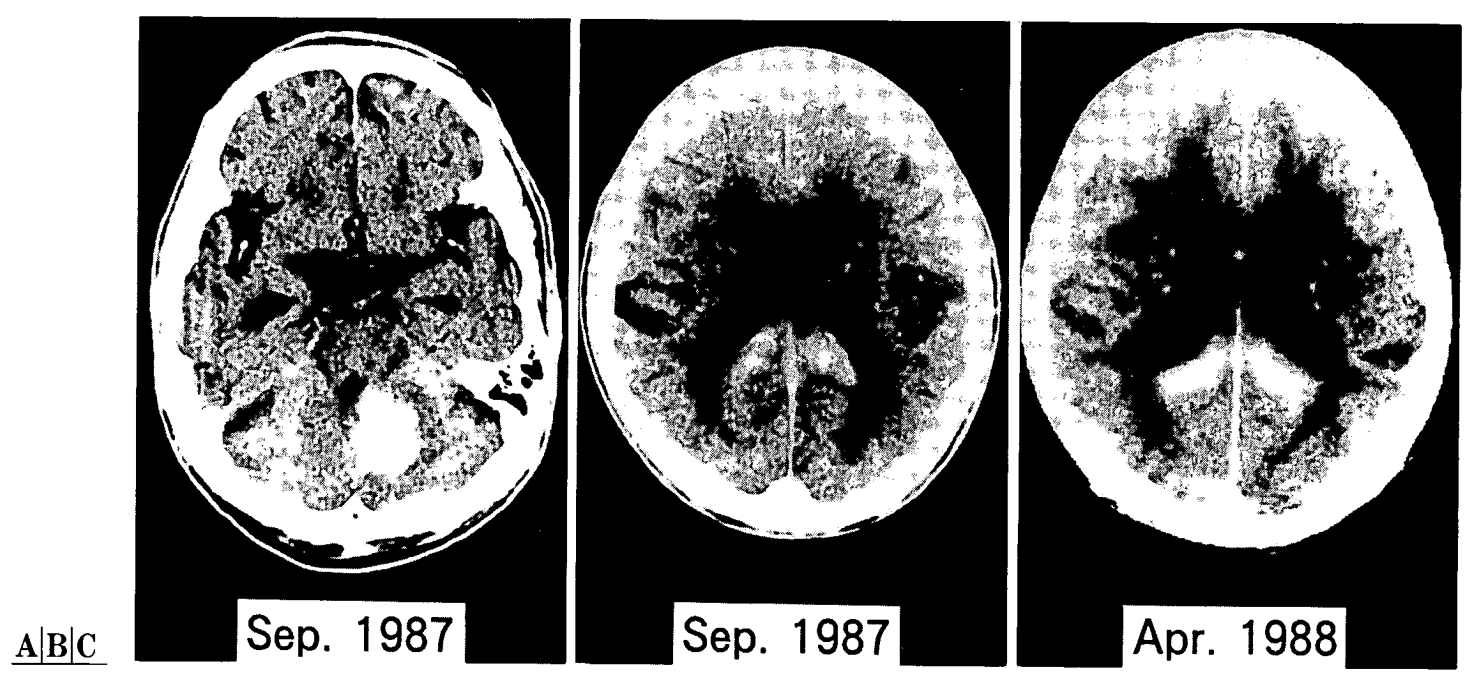

Fig. 3 CT scans of case 4

A, B : CT scans on initial admission, showing tumors in the cerebellar hemisphere and the splenium.

C : Recurrent tumor is found in the splenium, but the low density area in the cerebral white matter is quite extensive.

が進行し死亡に至った。以下にB群の代表的な症例を提 示する.

\section{【Case 10】}

患 者: 53 歳, 男

1982 年痙攣発作にて発症し, 当院神経内科入院. 頭部 CT 上大脳深部白質に多発性の CE を受ける病変を認め た (Fig. 2A). ステロイド投与を受け CT 上病変は消失 したため multiple sclerosis と診断され, その後外来に
て follow up されていたが, 1986 年前頭葉に病変の再発 を認めたため当科入院となった (Fig. 2B). 開頭による biopsy を施行し, diffuse large cell type $の$ non-Hodgkin's lymphoma と診断され, 全脳 $48 \mathrm{~Gy}$ の放射線治療 を行った. CE を伴う病変は消失したが, その後大脳深部 白質の低吸収域, 脳室拡大が出現した (Fig. 2C). V-P shunt を施行したが, 臨床的改善なくその後全身状態が 徐々に悪化し, 1987 年初回入院後約 7 年の経過で死亡し た. 


\section{【Case 4】}

患 者：75 歳, 男

精神症状, 歩行障害にて発症し, 1987 年 7 月当科に入 院. 頭部 CT 上小脳半球, 脳梁に多発性の homogeneous にCE を受ける病変を認め (Fig. 3A, B), PCNSL の臨 床診断で全脳 $48 \mathrm{~Gy}$ の放射線治療を受けた。画像上は $\mathrm{CR}$ となったが，臨床的には痴呆症状の改善が不良で あった. 1987 年 11 月脳梁に CE を受ける病変の再発を 認めたが，同時に CT 上両側対称性の大脳深部白質の著 明な低吸収域を認めた (Fig. 3C)。患者はその後徐久に全 身状態の悪化をきたし，1988 年 5 月 9 日死亡した。

\section{考察}

PCNSL はかつては稀な疾患とされていたが，近年そ の発生頻度の著しい増加が指摘されている.われわれの 施設に扔いても，1981〜1986 年までの 6 年間に経験した 初発症例は 3 例にすぎないのに対し, 1987〜1990 年まで の 4 年間で 11 例を経験している.さらに今回の検討には 含めながったが, 1991 年には 4 例の初発例を経験してお り，最近の症例数の増加を裏づけている．米国における 頭蓋内原発悪性リンパ腫の増加について, Eby ら ${ }^{6)}$ は, AIDS や臟器移植患者などの immunologically compromised host ではない，兔疫学的な risk factor を有 しない population においても, PCNSL が統計学的に 有意な増加を示していること, PCNSLの増加はsystemic non-Hodgkin's lymphoma の増加に並行せず，そ れを上回っていること，CT などの診断技術の進歩のみ での説明は困難であることを指摘しており，ordinally population における PCNSL の発生の絶対数そのもの の増加を示唆している.

PCNSL がステロイド投与により画像上縮小または消 失を示し得ることはよく知られている ${ }^{1111222}$ 。通常その 効果は一過性であるとされているが，われわれの Case 10 のようなステロイド投与のみによる長期緩解例も報 告されている22). ステロイドの作用機序については, 単 なる BBB の修復による contrast enhancement の消 退8)のではなく, lympho-reticular cell への cytotoxicity をステロイドが有すること, 前述のごとき長期緩解 例が存在することから, lymphoma cell に対する直接の cytotoxicity によるとする意見が多い12). 一方，ステロ イド投与により画像上縮小がみられた症例においては, 組織学的に退行性変化が中心となり, biopsyに扔いて PCNSL の診断が得がたくなることが報告されてお り7)，ステロイドの高い奏効率を考えると，臨床的に
PCNSL が疑われ，組織診断を予定している症例におい ては，術前のステロイド投与によりかえって診断過程が 混乱することが考えられ，緊急やむを得ない場合を除い てはステロイド投与は慎重に行うべきであると考えられ る.

PCNSL に対する外科的摘出の意義は今日では一般に

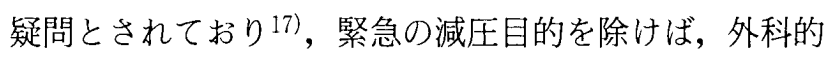
加療の意義は組織診断に限られることが多い。今回のわ れわれの検討では, 外科的治療はすべて biopsy, shunt あ るいは partial removal であったこともあり，検討から 除外した。一方, その著明な放射線感受性より, 従来よ り放射線照射が多くの場合第一選択とされ，今回のわれ われの検討でも示されているように，放射線治療により 多くの症例で $\mathrm{CR}$ が得られ，また生存期間の明らかな延 長が証明されている339) 18) 20). しかし未だ長期生存は稀 であり, 基本的に予後不良な疾患であるとの認識に変わ りはない。放射線治療については今日なお照射野, 線量, 脊髄照射の是非について異論があるが3(9) 18) 20), 放射線 治療のみで今後大きな治療成績の改善が得られる可能性 は少ないように思われる。これに対し PCNSLに対する 化学療法は, 従来放射線治療に伴う adjuvant therapy 招 よび再発症例に対する salvage therapyとして主に行わ れてきたが，前述のごとき放射線治療の限界が明らかに なるとともに，近年化学療法を第一選択とする治療の報 告が増加しつつある. Neuwlet ら ${ }^{16)}$ は Mannitol 動脈内 注入による Osmotic blood brain barrier disruption を 併用した combination chemotherapy により良好な成 績を報告しているわわれわの施設においても放射線治 療の限界を認識して, 最近の症例では CDDPを中心とし た化学療法を第一選択として試みている.

今回のわれわれの検討からは, 再発病変を含めて CT 上CE を示す nodular lesion を control することはそれ ほど困難とは思われなかった。むしろ治療経過中に出現 するCE を示さない主として大脳深部白質に広がる広範 な低吸収域が問題となるように思われた。 CT 上このよ うな所見が出現した時点では, 患者は廃人状態に近く, その後徐々に全身状態が悪化して死亡に至る経過をとつ た. 放射線治療後, 腫瘍の再発所見なく, 神経脱落症状, 痴呆症状が進行し, CT 上深部白質の低吸収域, 著明な 脳萎縮が出現する病態は, subacute brain atrophy after radiation therapy ${ }^{2)}$ として知られており，今回われわれ が検討した症例における病態も放射線治療による影響は 否定できない.しかしながら，放射線治療後のグリオー マ症例に対してその出現頻度がきわめて高率であるこ と，一部の症例では mass effect に乏しいながら明らか 
な enhanced lesion を伴っていることから, 放射線治療 のみに起因する病態とは考えがたいように思われる。一 般に PCNSL のCT 所見としては, homogeneous enhancement を呈する腫瘤性病変が代表的であるが，CE を伴わない低吸収域のみを示す PCNSL も少数ながら 報告されている. Bogdahn ら ${ }^{4)}$ は PCNSL の CT 所見 を 3 型に分類し，その一つとして CE を示さない低吸収 域がび漫性に脳内に広がってみられるび漫性脳内浸潤型 を記載している。また北川ら ${ }^{15)}$ ，風早ら ${ }^{14)}$ は頭部 CT 上 大脳白質に CE を示さない広範な低吸収域を呈し, 臨床 的に脳炎, Creutzfeldt-Jackob 病, PML, Binswanger 病等との鑑別が問題となり，剖検において PCNSL と診 断された症例を報告している。また腫瘤性病変を形成し ている場合においても，び漫性，浸潤性の発育を示しう ること ${ }^{1)}, \mathrm{CT}$ 像と剖検所見の対比より $\mathrm{CT}$ 上 $\mathrm{CE}$ を伴 う病変の消失が認められた部位においても tumor cell の残存が示されていること部，検例で生前 $\mathrm{CT}$ 上 $\mathrm{CE}$ がみられない部位に広範な腫瑒浸潤を示した症例が報告 されていること5)10)などを考慮すると，われわれの症例 に扔ける広範な低吸収域の出現も腫瘍浸潤に起因する可 能性が高いと考えられる。また，これら PCNSLにおけ る低吸収域の本態として，高い血管指向性を有する lymphoma cell による血管浸潤の結果としての虚血性機 序が議論されている13115)。

これらの文献的考察より今回のわれわれの症例にみら れた経過，すなわち enhanced nodule の再発を繰り返し た後, 大脳深部白質を中心とした広範な低吸収域の出現 をみるに至った状態は，広範な腫湯浸潤によるいわば PCNSL の末期像を示しているのではないかと考元られ た。また初回治療において痴呆症状を呈する多発病変例 で臨床症状の改善が不良であったことも，これらの症例 に扔いては CT 上 CE を呈する病変を越えて，すでに広 範な腫崵浸潤が起こっていることに起因するのではない かと思われた。

\section{文 献}

1）安芸都司雄, 中村恒夫, 市来崎潔, 岩田隆信, 戸谷重雄, 中野盛夫: Prednisolone が著効を呈した脳原発恵性り ンパ腫の1例. 脳神経 34:965-971，1982.

2) Asai A, Matsutani M, Kohno T, Nakamura O, Tanaka H, Fujimaki T, Funada N, Matsuda T, Nagata K, Takakura K : Subacute brain atrophy after radiation therapy for malignant brain tumor. Cancer $63: 1962$ $-1974,1989$.

3) Berry MP, Simpson J : Radiation therapy in the management of primary malignant lymphoma of the brain. Int J Radiat Oncol Biol Phys 7:55-59, 1981.

4) Bogdahn U, Bogdahn S, Mertens HG, Dommasch D, Wodarz R, Wunsch PH, Kuhl P, Richter E : Primary
non-Hodgkin's lymphoma of the CNS. Acta Neurol Scand 73:602-614, 1986.

5) Cellerier P, Chiras J, Gray F, Metzger J, Bories J : Computed tomography in primary lymphoma of the brain. Neuroradiology 26 : 485-492, 1984.

6) Eby NL, Grufferman S, Flannelly CM, Schold SC Jr, Vogel FS, Burger PC: Increasing incidence of primary brain lymphoma in the US. Cancer $62: 2461$ $-2465,1988$.

7) Feiden $W$, Bise K, Steude U : Diagnosis of primary cerebral lymphoma with particular reference to $\mathrm{CT}$ guided stereotactic biopsy. Virchows Arch 〔Pathol Anat] $417: 21-28,1990$.

8) Gerber AM, Savolaine ER: Modification of tumor enhancement and brain edema in computerized tomography by corticosteroids : case report. Neurosurgery $6: 282-284,1980$.

9) Gonzalez DG, Schuster-uitterhoeve ALJ : Primary non-Hodgkin's lymphoma of the central nervous system. Results of radiotherapy in 15 cases. Cancer 51 : 2048-2052, 1983.

10) Helle TL, Britt RH, Colby TV : Primay lymphoma of the central nervous system. Clinicopathological study of experience at Stanford. J Neurosurg 60:94-103, 1984.

11) Hochberg FH, Miller DC : Primary central nervous system lymphoma. J Neurosurg 68:835-853, 1988.

12) Homo-Delarche F : Glucocorticoid receptors and steroid sensitivity in normal and neoplastic human lymphoid tissues: a review. Cancer Res 44:431 $-437,1984$.

13) Jack CR Jr, Reese DF, Scheithauer BW : Radiographic findings in 32 cases of primary CNS lymphoma. AJNR 6:899-904, 1985.

14）風早靖子, 土井章弘, 浜家一雄：広範なび漫性浸潤を示 した中枢神経系原発悪性りンパ腫の 1 剖検例。脳神経 $44: 65-70,1992$.

15）北川泰久, 松岡康夫, 藤森一平, 花田徹野, 福田純也： 脳原発性悪性りンパ腫一 - C T 上造影滆增強効果をかく低 吸収域を認めた 1 剖検例。神経内科 $27: 364-366,1987$.

16) Neuwelt EA, Goldman DL, Dahlborg SA, Crossen J, Ramsey F, Roman-Goldstein S, Braziel R, Dana B : Primary CNS lymphoma treated with osmotic bloodbrain barrier disruption: prolonged survival and preservation of cognitive function. J Clin Oncol 9 : 1580 $-1590,1991$.

17) O'Neill BP, Illig JJ : Primary central nervous system lymphoma. Mayo Clin Proc 64:1005-1020, 1989.

18) Rampen FHJ, van Ander JG, Sizoo W, Unnik JAM : Radiation therapy of primary non-Hodgkin's lymphomas of the CNS. Eur J Cancer 16:177, 1980.

19) Sagerman $\mathrm{RH}$, Collier $\mathrm{CH}$, King GA : Radiation therapy of microglioma. Radiology 149:567-570, 1983.

20）新部英男, 玉木義雄, 渡辺俊一, 真崎規江, 掘内淳一, 早淵尚文, 金田浩一, 森田皓三: 中枢神経系の悪性リン パ腫一脳初発悪性リンパ腫の治療成績（日本悪性リンパ 腫放射線治療検討会 (JLRTG) 報告)。癌の臨床 34 ： 651-657, 1988.

21）須知泰山, 若狭治毅, 三方淳男, 難波紘二, 菊池昌弘, 森茂郎, 毛利 昇, 渡辺 昌, 社本幹博, 川島和雄, 張ヶ谷健一, 桐野有爾, 高木敬三, 福永真治, 板垣哲郎, 松田幹夫：非ホジキンリンパ腫病理組織診断の問題点 
一新分類の提案. 最新医学 $34: 2049-2062,1979$.

22) Vaquero J, Martinez R, Rossi E, Lopez R : Primary cerebral lymphoma : the 'ghost tumor'. Case report. $J$ Neurosurg 60:174-176, 1984.

23) Yasunaga $T$, Takahashi M, Uozumi H, Takada C,
Kawano S, Baba Y, Nakamura I, Sonoda H, Matsukado $\mathrm{Y}$ : Radiation therapy of primary malignant lymphoma of the brain. Acta Radiol Oncol 25:23 $-28,1986$.

\section{要旨}

中枢神経系原発悪性リンパ腫の䧎床的検討

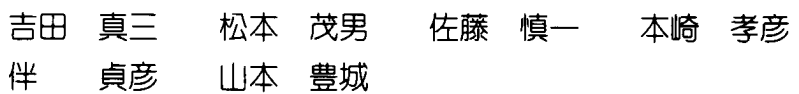

放射線治療を中心とする初回治療を行つた14例の中枢神経系原発悪性リンパ腫の䧣床的検討を 行つた. CT上 contrast enhancement を示す病变は, 初回治療中の死亡1例を除く全例にお いて完全消失を示したが, 画像上の改善と臨床症状の改善は必ずしも一致せず, 痴呆症状の改善は不 良であつた.

Follow up 中における死亡 9 例のうち, CE を示す腫瘤の再発, 増大によると考えられる死亡は 2 例のみであり, その他の症例は CT上脳室拡大, 大脳深部白質に広範な低吸収域を示し, 痴呆症状 から徐マに全身衰弱をきたし死亡に至るという経過をとつた. 治療経過中に出現するこの広範な低吸 収域の本態の解明が治療成績の向上のうえで重要な課題と考えられた。 